\section{Grazing in the Middle East: Past, Present, and Future ${ }^{1}$}

\section{KENNETH PEARSE2}

Project Manager, Pasture and Fodder Crop Investigations Project, United Nations Development Program, Food and Agriculture Organization, Tehran, Iran

\section{Highlight}

Grazing of native range lands by domestic livestock began in the Middle East, probably about 11,000 years ago. Too early and too heavy grazing doubtless occurred locally since earliest times but for many millennia the pressure of man and his animals had only limited impact on the environment. Within the last century unmanaged grazing increased greatly. Depletion is now serious over much of the area. Lack of management is not due to lack of a technical, legal, or administrative basis for action but rather to lack of appreciation of the seriousness of the problem and lack of desire to act. The primary aim of technical assistance should not be to provide more technical knowledge. Local understanding of the range problem and determination to find workable solutions are the urgent needs.

\section{The Beginnings}

The history of grazing of native forage producing lands by domestic livestock began in the Middle East. It was in the foothills or "hilly flanks" of this region that the domestication of grazing animals began probably about 11,000 years ago (Butzer, 1964; Ucko and Dimbleby, 1969). There is good archeological evidence that the goat existed as a domestic animal at many settlements in what is now Iran, Iraq, Jordan, and Israel before the seventh millennium B.C. (Reed, 1959). Evidence indicates that sheep were first domesticated about 1,000 years later. Cattle were probably domesticated about 6200 B.C. in Greece and the horse and ass somewhat later. It is certain that all of these species were in widespread use from the Nile to the Indus more than 5,000 years ago.

The domestication of herbivores was one part of the Neolithic Revolution which still ranks as one of the most significant events of history (Langer, 1952). Other essential aspects of this "Food Producing" revolution were the beginnings of crop agriculture through the domestication of wheat, barley

\footnotetext{
1. Received February 13, 1970; accepted for publication June 14, 1970.

2 Present address is Treasure Island 740, Laguna Beach, California.
}

and other food plants and the making of pottery. These three developments made possible the production and storage of an assured food supply and freed man from the daily hunt and food gathering. They made a settled existence possible and led to the establishment of villages.

No doubt prehistoric man began to graze too many goats and to practice too early grazing in the immediate vicinity of his camps as soon as he built up his first flock. But for thousands of years this mattered little. He and his animals were too few in number to have much impact on the vast reaches of virgin rangelands (Butzer, 1964).

In this semi-arid region it was natural that early man would observe the advantages of leading water from small springs to his croplands or of taking advantage of natural flooding of wadi bottoms to grow better crops. His knowledge of irrigation and water control accumulated until he was finally able to move down to the fertile alluvial flood plains and to irrigate them with the ample waters of the great rivers. This set the stage for the Urban Revolution and the development of the cities and city-states in the many broad valleys where large scale irrigated agriculture and stock raising could be practised. The great ancient civilizations of the Indus valley, Mesopotamia, Syria, Palestine and Egypt were founded as early as 4000 B.C.

As a result of the growth in population and its concentration in the cities, man began to have more impact on his environment. Timber was cut for the construction of buildings, ships and other works and fuel was gathered for cooking, heating and the firing of bricks and pottery. Flocks must have been large enough to seriously deplete the range for scores of miles around the major cities.

The history of the ancient civilizations of the Middle Fast is a recurring pattern of great accomplishment and flourishing economies interrupted by decline and decay. This pattern has been repeated again and again, both in time and in space.

Some civilizations undoubtedly fell because of early man's failure to adjust to his environment. In other cases historians are convinced that the fall of the cities was the result of internal strife, loss of authority of the ruler, economic crises and finally invasion by neighboring peoples. Epidemic disease and famines also took their toll. All of these forces served to hold populations in check enough to prevent the extreme damage to the range that otherwise would have occurred. Nevertheless populations built up slowly and pressure on the resources continued.

Over the centuries this pressure had its effect. Today's traveller finds it almost impossible to believe that most of the now barren slopes and mountains with annual precipitation in excess of 12 inches were once forested. Yet ecological studies have permitted the accurate tracing of the former extensive forests of oak, juniper, pistachio and almond where only a few stunted remnants are now found (Bobek, 1968).

The influence of uncontrolled grazing is also evident. The ground cover of the depleted forests is now mainly composed of thorny, un- 


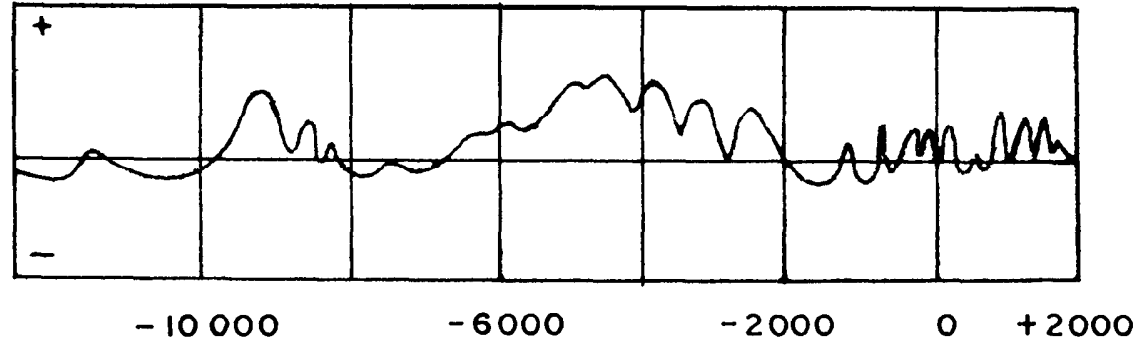

Fig. 1. Main trends of precipitation (hypothetical) in Middle East since about 12000 B.C. Source: Butzer, 1961 .

palatable tragacanth species. The steppic and sub-steppic vegetation has changed from a mixture of palatable grasses, legumes and other good forage plants to low value annuals, thistles and worthless weeds.

As to the timing of these changes, detailed studies have led Bobek (1968) to conclude that "One is probably right in assuming that vegetal conditions in Iran were at their optimum during the third and second millennia B.C. There is some evidence for believing that they were much better in the first millennium B.C. and probably for a good span of time afterwards compared with conditions today. No doubt the many centuries of .... mismanagement have greatly contributed to progressive deterioration, which would seem to have accelerated in modern times." It is reported that "as recently as the sixteenth century most of the mountain slopes and uplands were covered with stands of trees, brush and grass." (Cento, 1964).

Thus the influence of man and his grazing animals began to affect the well-being of range-watershed lands from the very earliest times. Sparse populations and scattered settlement at first limited man's impact on his cnvironment. Over the centuries the slow build-up of populations, the development of city-states and the increased exploitation of the forest and rangelands has had a marked effect on the vegetation and soil.

The possibility that climatic changes might have been responsible for the ebb and flow of civilizations and the deterioration of the vegetation must be considered. There is convincing archeological, geologic and geomorphic evidence that from the close of the sixth to the close of the third millennia B.C. the region enjoyed a period of relatively ample rainfall (Fig. 1). This was followed shortly before 2000 B.C. by a period of desiccation. The evidence indicates that for the past 4,000 years the climate of the area has fluctuated around a mean closely resembling that of the present and that the fluctuations are no more than the alternations of moist and dry years that have occurred since time immemorial (Butzer, 1961). According to Bobck (1968) "For many centuries climatic conditions in the region have not deteriorated."

\section{Recent Developments}

A trend which greatly affected the use of natural resources of the
Middle East started toward the end of the last century. At about that time some central governments increased their strength and influence enough so that more political stability and economic and social progress could be achieved. Invasions and warfare began to subside. In some countries relative stability was soon reached; in others this development has been recent. Stability is still far from being accomplished throughout the region but at least the devastating invasions as well as the constant tribal raids have been held in check. And the form of strife hạs changed so that no longer are whole populations wiped out and their livestock destroyed.

Another recent development was the reduction of the ravages of epidemic diseases and famine through national and international public health programs.

The result of these developments has been a spectacular population build-up. In Egypt, for example, the population remained at about 3 million persons for more than 18 centuries after the time of Christ. After 1800 it began to increase, doubling by 1870 . It doubled again by 1910 and again by 1950 . It will reach 40 million by 1975 (Fig. 2). Similar population explosions have occurred throughout the region.

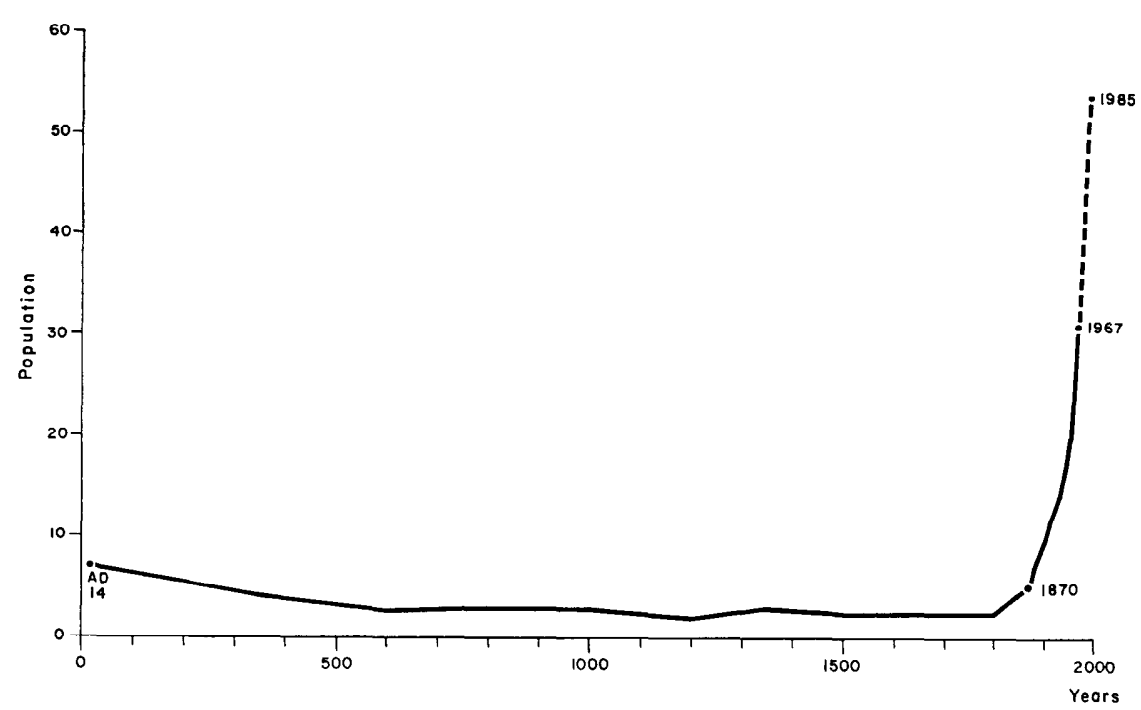

FIG. 2. Human population, Egypt, A.D. 14- 1985, in millions. Source: A.D. 141962, Clark, Colin. Population growth and land use. Macmillan, London, 1967; 1963- 1985 United Nations Statistical Office. New York. 


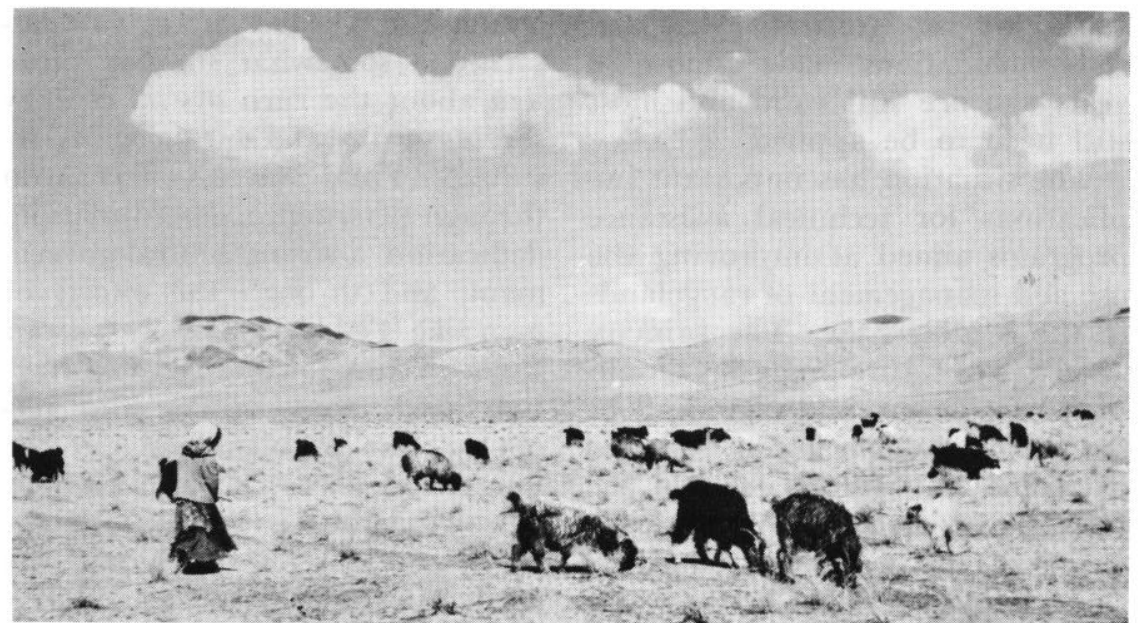

FIG. 3. Most Middle East range lands are in very poor condition as a result of recent increase in livestock numbers and lack of management. Darab, Iran.

This has brought about a corresponding increase in use of the range resource. The numbers of man's animals increased as the population increased. While records of livestock populations are scanty and often inaccurate those that are available indicate that numbers of sheep, goats and other range livestock have about doubled during the last thirty years. Figures of this order of magnitude have been quoted from Iran, Pakistan, Sudan and Turkey (Pearse, 1968; Lodge, 1965; Shepherd, 1968; Min. of Agri., Turkey, 1968).

Other factors have further aggravated the pressure on the range resource during the past few decades. These include increased fuel gathering, plowing of rangelands for cereal production, development of livestock watering places in previously unusable areas and establishment of veterinary and supplemental feeding programs which only serve to keep more animals alive to overgraze the range. It was estimated in 1964 that the number of range animals in Iran was 12 times the grazing capacity of the usable ranges (Cento 1964). A detailed study of the grazing lands of 16 Central Anatolian villages found that to avoid further damage to the range and soil $92 \%$ of the animals should be excluded (Erkun, 1964).

To summarize, it can only be sands of years they concluded that Middle East ranges must have extraordinary resistance. This conclusion was in error. Middle East ranges have been misused for perhaps several centuries but only in the past few decades has this become so serious and widespread.

\section{The Future}

With present overstocking range deterioration will continue and even accelerate. Regardless of any corrective action that may be taken the trend will continue downward on many ranges for some time to come.

There is little indication that improved range management will be applied on a significant scale in the near future. This is so in spite of the fact that technical assistance programs since the early 1950's have made good progress in developing the technical, legal and administrative basis for action.

The technical knowledge for rehabilitating most Middle East ranges and placing them under rational management already exists. In each country technical assistance studies have shown how the principles of range management developed elsewhere could be adopted and applied to local conditions (Ibrahim, 1967). In some countries corrective measures have been applied on a small scale or for a few years on jointly operated experimental or demonstrational ranges. sures had been operating for thou-

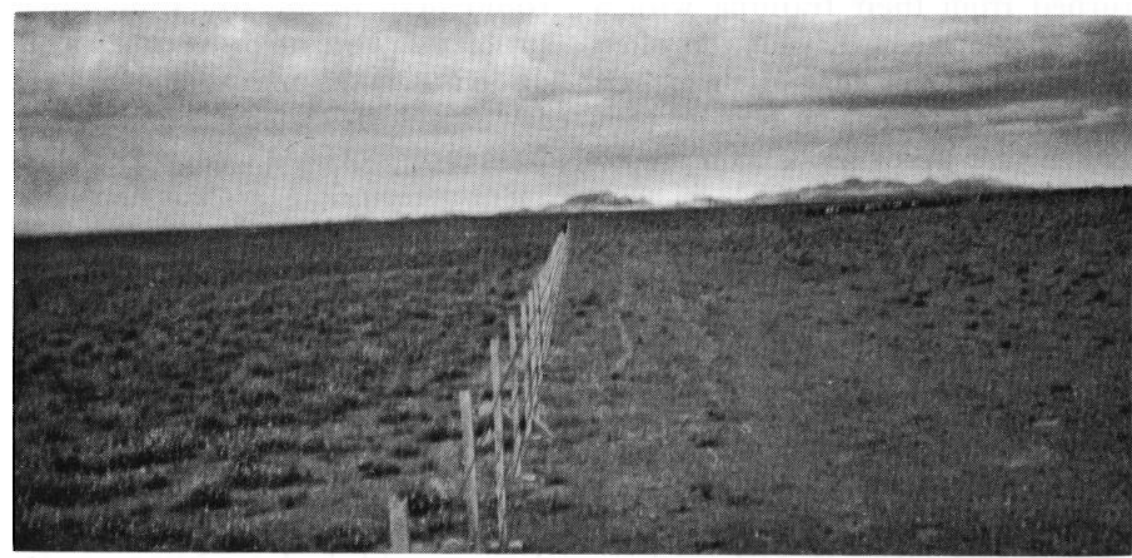

FIG. 4. Recovery of the better forage plants is frequently rapid following the control of grazing. Artemisia herba-alba-Stipa barbata with less than $200 \mathrm{~mm}$ precipitation. Right, grazed by village sheep; left protected two years. Rudshur, Iran. 
The recovery of the vegetation under proper management has proved remarkable in many places (Fig. 4). Although continuing research is still needed, technical knowledge is now adequate to begin extensive range improvement and management programs.

The necessary legal basis for action also exists in most of the countries and could be established in others. It is true that some of the range laws are very general and means to implement them are lacking. But the legal foundation has been laid and this can give an effective basis for action.

Range departments, services or other administrative bodies have been established. These bodies are charged with the tasks of conducting research, carrying out surveys and preparing management plans. They are empowered to make and enforce regulations for the control of grazing. In most cases these units need strengthening and additional budget and staff but the organization has been established.

Lack of trained local technicians to staff the range departments and to carry out the management programs has been cited as a reason for lack of progress. While this may be a factor, it does not appear to be necessarily limiting. Hundreds of selected young men have received training in range management and related fields. Many have earned B.Sc. or higher degrees. Many are capable and have returned from their training with a strong desire to act. But too often they soon begin to feel that their chosen field lacks support and they either give up or move to more rewarding fields.

Lack of progress does not appear to be due to lack of an effective basis for action but rather to failure to recognize the seriousness of the range problem and lack of desire to attack it. There seems to be no other explanation for the failure to put into effect the recommendation of the hundreds of technical assistance reports that have been submitted to the governments (Ibrahim,
1967). It is significant that the recommendations made almost 20 years ago are still valid and most still need to be applied.

The situation has important implications for technical assistance programs aimed at improving the use and management of rangelands in the Middle East. The primary objective of future programs should be to foster an understanding of the range problem and a desire to overcome it. Efforts should be focused on making the people aware of the widespread and extreme depletion of the range-watershed lands, of the serious effects on the national well-being, and of the need for and possibilities of corrective action. All of the people, from the man on the street, to the livestock owner, to the highest government official need to be convinced.

How best to do this deserves much thought. Perhaps a few well conceived demonstration ranges where grazing could be controlled and good management applied over a long enough period to show the responses would be effective. Opcration would have to be continued for at least ten years regardless of changes in personnel or policies. Full control of the land and the animals must be in the hands of the technicians. The objective should be clearly understood to be demonstration of good range management, not research or testing.

Perhaps there are other new ways through which technical assistance could help in an attack on range problems. One might be to assist in applying good management on a few carefully selected grazing allotments provided that the government agreed that this was desirablc. All possibilities should be carefully explored. Continued use of the traditional approaches will not be effective except to the extent that they help to develop interest and stimulate a desire for action.

Whatever is done the difficulties ahead cannot be overestimated. Long established tradition, vested interests, and delicate political balances all combine to delay change.
When the United States first attacked a somewhat similiar problem about the turn of the century severe strains and bitter fights resulted. Final success was won through persistence, determination, dedication, a strong central government, and through the efforts of men like Teddy Roosevelt, Gifford Pinchot, Jim Jardine, W. C. Chapline, and many others who recognized the problem and put the long term needs of society above personal ambitions and expediency. The same prerequisites will be needed in the Middle East.

\section{Literature Cited}

Вовек, Н. 1968. Cambridge history of Iran. Vol. I. University Press. Cambridge. p. 280.

Butzer, K. W. 1961. A history of land use in arid climates; climatic change in arid regions since the pliocene. UNESCO. Paris, p. 31.

Butzer, K. W. 1964. Environment and archeology, an introduction to Pleistocene geography. Aldine Publishing Co., Chicago.

Cento. 1964. Iravelling seminar on range management. Cento, Ankara.

ERKun, V. 1964. Investigation on Bala County grazing lands. Typescript, unpublished. Ankara.

IBRAHIM, K. M. 1967. The pasture, range and fodder crop situation in the Near East. FAO., PL: PFC/I, Rome.

Langer, W. L. (ed.) 1952. An encyclopedia of world history. Houghton Mifflin Co., N.Y.

LODge, Robert W. 1965. Report to the government of Pakistan. Range Management Research in West Pakistan. FAO., TA 1968, Rome.

Ministry of Agriculture, Turkey. 1968. Trends in Turkish agriculture, 1938-66. Ankara.

Pearse, C. Kenneth. 1968. A range, pasture and fodder crop research program for Iran. FAO., Tehran.

ReED, C. 1959. Animal domestication in the prehistoric Near East. Science, Vol. 130, p. 1629-1639.

ShEPHERD, W. C. 1968. Report to the government of Sudan. Range and Pasture Management. FAO., TA 2468, Rome.

Ucko, P. J., and G. W. Dimbleby. 1969. The domestication and exploitation of plants and animals. Aldine Publishing Co., Chicago. 